\title{
Significant Association of MMP2 Promoter Genotypes to Asthma Susceptibility in Taiwan
}

\author{
LI-HSIOU CHEN ${ }^{1,2^{*}}$, KUO-LIANG CHIU ${ }^{2,3^{*}}$, TE-CHUN HSIA ${ }^{4 *}$, YEN-HSIEN LEE ${ }^{2}$, TE-CHUN SHEN ${ }^{1,4}$, \\ CHIA-HSIANG LI ${ }^{1,4}$, YI-CHENG SHEN ${ }^{1,4}$, WEN-SHIN CHANG $^{1,4}$, CHIA-WEN TSAI $^{1,4}$ and DA-TIAN BAU ${ }^{1,4,5}$ \\ ${ }^{1}$ Graduate Institute of Biomedical Sciences, China Medical University, Taichung, Taiwan, R.O.C.; \\ ${ }^{2}$ Division of Chest Medicine, Department of Internal Medicine, \\ Taichung Tzu Chi Hospital, Taichung, Taiwan, R.O.C.; \\ ${ }^{3}$ School of Post-Baccalaureate Chinese Medicine, Tzu Chi University, Hualien, Taiwan, R.O.C.; \\ ${ }^{4}$ Terry Fox Cancer Research Laboratory, Department of Medical Research, \\ China Medical University Hospital, Taichung, Taiwan, R.O.C.; \\ ${ }^{5}$ Department of Bioinformatics and Medical Engineering, Asia University, Taichung, Taiwan, R.O.C.
}

\begin{abstract}
Background/Aim: Matrix metalloproteinase 2 (MMP2) is reported to be overexpressed in asthma; however, its genotypic contribution to asthma is not well studied. Therefore, we examined the association of MMP2 genotypes with asthma risk among Taiwanese. Materials and Methods: One hundred and ninety-eight asthma patients and 453 nonasthmatic subjects were determined with respect to their MMP2 -1306 (rs243845) and -735 (rs2285053) genotypes. Results: CT and TT at MMP2 rs243845 are $17.7 \%$ and $1.5 \%$ among asthma cases, whereas their presence in healthy subjects is at $28.1 \%$ and $2.4 \%$, respectively ( $p$ for trend=0.0118). In detail, the CT genotype in MMP2 rs243845 was associated with a decreased asthma risk [adjusted odds ratio $(O R)=0.57,95 \%$ confidence interval $(C I)=0.37-0.78, p=0.0040]$, and the $T$ allele conferred $a$ significantly lower asthma risk compared to the wild-type $C$ allele (adjusted $O R=0.55,95 \% C I=0.43-0.77, p=0.0042$ ). No significance was found for MMP2 rs2285053. Conclusion: The genotype of CT in MMP2 rs243845 may serve as a novel biomarker in determining susceptibility to asthma in Taiwan.
\end{abstract}

This article is freely accessible online.

*These Authors contributed equally to this work.

Correspondence to: Da-Tian Bau, Terry Fox Cancer Research Laboratory, Department of Medical Research, China Medical University Hospital, 2 Yuh-Der Road, Taichung, 404 Taiwan, R.O.C. Tel: +886 422053366 (Ext. 5805), e-mail: datian@mail.cmuh.org.tw; artbau2@gmail.com

Key Words: Asthma, genotype, MMP2, polymorphism, promoter, Taiwan.
Asthma, typically characterized by airflow obstruction, airway inflammation and remodeling, is a complex disease with variable phenotypes in triggering coughing, making a wheezing sound and causing shortness of breath $(1,2)$. Over the past 30 years, the number of patients diagnosed with asthma has significantly increased (3), collectively comprising more than 300 million cases all over the world (4). In 2017, the annual global incidence of asthma was 43.12 million new cases $(0.56 \%)$, while global prevalence and mortality accounted for 272.68 million cases $(3.57 \%)$ and 0.49 million deaths $(0.006 \%)$, respectively (5). Etiologically, asthma is determined by a complex interaction of genomic and environmental factors, while the contribution of heritability to the susceptibility to asthma has been estimated to vary between 36 to 79 percent $(6,7)$. Although the concept that the genetic inheritance plays a role in the pathogenesis of asthma has been recognized for more than one century (3), the exact mechanisms of asthma etiology are still poorly understood while asthma is believed to progresses with lots of unidentifiable and unpredictable causes. Following the code-breaking of human genome, more than 200 asthma candidate genes have been proposed $(8,9)$. Still, although it is intensely studied, lots of difficulties remain in figuring out the role of the specific causal genes and determining whether ethnic disparities should be attributed to the genetic control of certain factors leading to asthma.

Extracellular matrix (ECM) components play a critical role in providing support for surrounding cells and in regulating the remodeling of the cell micro-environment (10). Similarly, with the progression of asthma the airway undergoes structural and biochemical remodeling (11). Matrix metalloproteinases (MMPs), also known as matrixins, are a group of endopeptidases involved in ECM remodeling by degrading ECM components $(10,12)$. Many MMPs are 
involved with the pathogenesis and modulation of the severity of asthma, among which, MMP-9 is the predominant one; however, MMP-2 is also gaining ground (13).

From the viewpoint of genetic contribution towards asthma risk, the $M M P 9$ gene has been examined a few times (14-21), while MMP2 has not (13). The latter, composed of 12 introns and 13 exons, is located on chromosome 16q21 in the human genome (22). The MMP2 promoter C-1306T (rs243865) and C-735T (rs2285053) polymorphisms have been reported to affect the expression of MMP2 at both mRNA and protein levels, leading to variable susceptibilities to several types of cancer, including oral, nasopharyngeal, esophageal, breast, lung, and colon cancer (23-28). In addition, MMP2 has been found to be upregulated among patients with oral squamous cell carcinoma, especially those with lymph node metastasis (29). The only study investigating the contribution of $M M P 2$ polymorphisms to asthma is by Toujani and his colleagues, who have reported that these are not associated with asthma risk in a population containing 150 asthma cases and 150 controls (13). Most importantly, MMP2 protein is in charge of the degradation of its various substrates, including MMP-13, and fibrillar collagen, elastin, endothelin, fibroblast growth factor, plasminogen, TGF- $\beta$, as well as MMP9 (30). Based on the evidence above showing that $M M P 2$ genotypes may also involve in the susceptibility determination of asthma as other human diseases, the present case-control study aims at examining the contributions of $M M P 2$ promoter C-1306T (rs243865) and C-735T (rs2285053) polymorphisms to the susceptibility of asthma in Taiwan.

\section{Materials and Methods}

Cohort. A total of 198 patients with asthma were recruited at the China Medical University Hospital from 2008 to 2010. Their medical histories were reviewed, and the data were collected into the hospital database. At the same period, 453 healthy individuals, matched with these patients by age ( \pm 5 years), were admitted to the exact same hospital for their health checkup (similar residential areas and same background, i.e. Taiwanese) with no previous diagnosis of neoplastic disease or any malignancy and were selectively enrolled into our matched control group. All the participants enrolled in this study were asked to provide their informed consent for publishing their tissue analysis results and other data. All the protocols of the current study were approved by Human Research Committees of China Medical University hospital (CMUH106-REC1-004). From each participant, $5 \mathrm{ml}$ of venous blood sample was collected and used for DNA extraction and subsequent genotyping as described below. Demographics of the cohort and controls have also been used in our previous study (31) and are summarized in Table I.

$M M P 2$ genotyping. Each participant's genomic DNA was extracted from peripheral blood leukocytes within $24 \mathrm{~h}$, carefully quantitated, diluted and stored at $-80^{\circ} \mathrm{C}$ until further processing, as previously described (31-34). In the current study, the genotypes at MMP2 -
Table I. Distribution of age and gender among the 198 asthma patients and 453 controls (from 31).

\begin{tabular}{|c|c|c|c|c|c|}
\hline \multirow[t]{2}{*}{ Index } & \multicolumn{2}{|c|}{ Controls $(\mathrm{n}=453)$} & \multicolumn{2}{|c|}{ Cases $(n=198)$} & \multirow[t]{2}{*}{$p$-Value } \\
\hline & $\mathrm{n}$ & $\%$ & $\mathrm{n}$ & $\%$ & \\
\hline \multicolumn{6}{|c|}{ Age (years) } \\
\hline $25-40$ & 285 & $63.4 \%$ & 133 & $67.2 \%$ & \\
\hline$>40$ & 168 & $36.6 \%$ & 65 & $32.8 \%$ & 0.2972 \\
\hline \multicolumn{6}{|l|}{ Gender } \\
\hline Male & 190 & $41.9 \%$ & 83 & $41.9 \%$ & \\
\hline Female & 263 & $58.1 \%$ & 115 & $58.1 \%$ & 0.9956 \\
\hline
\end{tabular}

aBased on chi-square without Yate's correction test.

1306 (rs243845) and -735 (rs2285053) were determined for all the investigated subjects via polymerase chain reaction-restriction fragment length polymorphism (PCR-RFLP) using BioRad Mycycler (BioRad, Hercules, CA, USA). All PCR reactions were uniformly performed using the primers presented in Table II and the following thermal program: i) an initial cycle at $94^{\circ} \mathrm{C}$ for $5 \mathrm{~min}$, ii) 40 cycles of $94^{\circ} \mathrm{C}$ for $30 \mathrm{~s}, 55^{\circ} \mathrm{C}$ for $30 \mathrm{~s}$, and $72^{\circ} \mathrm{C}$ for $30 \mathrm{~s}$, and iii) a final extension at $72^{\circ} \mathrm{C}$ for $10 \mathrm{~min}$. The PCR DNA amplicons were digested by the corresponding restriction endonucleases Xsp I and Hinf I (New England Biolabs, Taipei, Taiwan) (Table II) overnight, and their fragment were separated by $3 \%$ agarose gel electrophoresis under 100 Volt, stained with ethidium bromide, observed and taken pictured under UV-irradiation, and finally identified of their individual genotypes. All genotypic procedures were repeated by at least two researchers independently and blindly, and their results turned out to be $100 \%$ concordant with each other.

MMP2 genotype analyzing methodologies. The Student's $t$-test was applied for the comparison of age index between the asthma and the control groups. Pearson's chi-square or Fisher's exact test (when a number was less than 5) is applied to compare the distributions of the numbers among the subgroups. The Hardy-Weinberg equilibriums were checked by chi-square goodness-of-fit test $(p>0.05)$ using gene frequencies of the healthy individuals in the control group. The associations between MMP2 genotypes and asthma risk were estimated by calculating the odds ratios (ORs) and their $95 \%$ confidence intervals (CIs) from logistic regression analysis. Statistically, any difference between any two groups compared with $p<0.05$ was considered significant.

\section{Results}

The frequency distributions of selected demographic indexes, such as age and gender for the 198 asthma patients and 453 non-asthmatic controls have also been used in our previous study (31) and are presented in Table I.

The distribution of the MMP2 rs243865 and rs2285053 genotypes among the 198 asthma cases and the 453 nonasthmatic controls are presented and compared in Table III. First, the distributions of genotypes of both MMP2 rs243865 and rs2285053 in control and case groups fit well with Hardy-Weinberg Equilibrium (all $p>0.05$ ). Second, the 
Table II. Reagents used for MMP2 PCR-RFLP genotyping.

\begin{tabular}{|c|c|c|c|}
\hline$M M P 2$ polymorphic site & Primer sequences & $\begin{array}{l}\text { Restriction } \\
\text { endonuclease }\end{array}$ & $\begin{array}{l}\text { Amplicon sizes } \\
\text { after digestion }\end{array}$ \\
\hline rs 243845 & $\begin{array}{l}\text { F: 5'-CTTCCTAGGCTGGTCCTTACTGA-3' } \\
\text { R: 5'-CTGAGACCTGAAGAGCTAAAGAGGT-3, }\end{array}$ & Xsp I & $\begin{array}{l}\text { C: } 188+5 \text { bp } \\
\text { T: } 162+26+5 \text { bp }\end{array}$ \\
\hline rs2285053 & $\begin{array}{l}\text { F: 5'-GGATTCTTGGCTTGGCGCAGGA-3' } \\
\text { R: 5'-GGGGGCTGGGTAAAATGAGGCTG-3' }\end{array}$ & Hinf I & $\begin{array}{l}\text { C: } 391 \mathrm{bp} \\
\text { T: } 338+53 \mathrm{bp}\end{array}$ \\
\hline
\end{tabular}

PCR-RFLP: Polymerase chain reaction restriction fragment length polymorphism; F: forward; R: reverse; bp: base pair.

results show that the genotype of $M M P 2$ rs2285053 among Taiwan citizens are not differently distributed between the asthma patients and the healthy control groups (Table III bottom part). Third, interestingly, the genotypes of $M M P 2$ rs243845 are differentially distributed between the two groups ( $p$ for trend $=0.0118$ ) (Table III top part). In detail, the MMP2 rs243845 heterozygous variant CT was associated with a decreased asthma risk, compared to the wild-type CC genotype (adjusted OR=0.57, 95\% CI $=0.37-0.78, p=0.0040$; Table III top part).

Concerning the homozygous variant TT in MMP2 rs243845, this was not associated with a significantly altered asthma risk, compared to the wild-type CC genotype (adjusted $\mathrm{OR}=0.66,95 \% \mathrm{CI}=0.19-1.98, p=0.3377$; Table III top part). To confirm these findings, we put the CT and TT groups into one. The results show that there is an association between the CT+TT genotype at MMP2 rs2285053 and decreased asthma risk, compared to CC wild-type genotype in the dominant model analysis, (adjusted $\mathrm{OR}=0.58$, $95 \% \mathrm{CI}=0.38-0.77, p=0.0029$, Table III top part).

To confirm the novel findings presented in Table III, we also analyzed the allelic frequency distribution of MMP2 rs243845 and rs2285053 (Table IV). The results show that the variant $\mathrm{T}$ allele in $M M P 2 \mathrm{rs} 243845$ was associated with a relatively lower asthma risk compared to the wild-type C allele. On the other hand, the T allele in MMP2 rs243845 was not a determinant of asthma risk for Taiwanese. In detail, the variant allele $\mathrm{T}$ was found to be at $10.4 \%$ in the asthma group, much lower compared to the $16.4 \%$ in the control group (adjusted $\mathrm{OR}=0.55,95 \% \mathrm{CI}=0.43-0.77$, $p=0.0042$ (Table IV top part). On the contrary, there was no such significant difference in MMP2 rs2285053 between the two groups examined (Table IV bottom part).

\section{Discussion}

In the current study, the contribution of $M M P 2$ to Taiwan asthma risk is firstly revealed among a representative population containing 358 asthma patients and 716 age- and gender-matched non-asthmatic subjects in Taiwan. Our results suggest that the heterozygous variant CT genotype of MMP2
Table III. Distribution of MMP2 genotypes among asthma patients and healthy subjects.

\begin{tabular}{lcccc}
\hline & $\begin{array}{c}\text { Cases, } \\
\mathrm{n}(\%)\end{array}$ & $\begin{array}{c}\text { Controls, } \\
\mathrm{n}(\%)\end{array}$ & $\begin{array}{c}\text { Adjusted OR } \\
(95 \% \mathrm{CI})^{\mathrm{a}}\end{array}$ & $p$-Value $^{\mathrm{b}}$ \\
\hline rs243845 & & & & \\
CC & $160(80.8)$ & $315(69.5)$ & 1.00 (Reference) & \\
CT & $35(17.7)$ & $127(28.1)$ & $0.57(0.37-0.78)$ & $\mathbf{0 . 0 0 4 0}$ \\
TT & $3(1.5)$ & $11(2.4)$ & $0.66(0.19-1.98)$ & 0.3377 \\
CT+TT & $38(19.2)$ & $138(30.5)$ & $0.58(0.38-0.77)$ & $\mathbf{0 . 0 0 2 9}$ \\
$P_{\text {trend }}$ & & & & $\mathbf{0 . 0 1 1 8}$ \\
$P_{\text {HWE }}$ & & & & 0.6685 \\
rs2285053 & & & & \\
CC & $136(68.7)$ & $294(64.8)$ & $1.00($ Reference $)$ & \\
CT & $54(27.3)$ & $138(30.6)$ & $0.88(0.63-1.21)$ & 0.3809 \\
TT & $8(4.0)$ & $21(4.6)$ & $0.84(0.59-1.32)$ & 0.6498 \\
CT+TT & $62(31.3)$ & $159(35.2)$ & $0.85(0.61-1.27)$ & 0.3480 \\
$P_{\text {trend }}$ & & & & 0.6427 \\
$P_{\text {HWE }}$ & & & & 0.3573 \\
\hline
\end{tabular}

OR: Odds ratio; CI: confidence interval; HWE: Hardy-Weinberg Equilibrium; ${ }^{a}$ Data has been adjusted for confounding factors including age, gender and smoking. 'Based on Chi-square test without Yates' correction or Fisher's exact test (as any number is less than 5). Bold values indicate statistical significance.

Table IV. Distribution of MMP2 allelic frequencies among asthma patients and healthy subjects.

\begin{tabular}{crccc}
\hline Allelic type & $\begin{array}{c}\text { Cases, } \\
\mathrm{n}(\%) \\
\mathrm{n}=396\end{array}$ & $\begin{array}{c}\text { Controls, } \\
\mathrm{n}(\%) \\
\mathrm{n}=906\end{array}$ & $\begin{array}{c}\text { Adjusted OR } \\
(95 \% \mathrm{CI})^{\mathrm{a}}\end{array}$ & $p$-Value \\
\hline rs243845 & & & & \\
Allele C & $355(89.6)$ & $757(83.6)$ & 1.00 (Reference) & \\
$\begin{array}{c}\text { Allele T } \\
\text { rs2285053 }\end{array}$ & $41(10.4)$ & $149(16.4)$ & $0.55(0.43-0.77)$ & $\mathbf{0 . 0 0 4 2}$ \\
Allele C & $326(82.3)$ & $726(80.1)$ & 1.00 (Reference) & \\
Allele T & $70(17.7)$ & $180(19.9)$ & $0.88(0.69-1.13)$ & 0.3559 \\
\hline
\end{tabular}

OR: Odds ratio; CI: confidence interval. aData has been adjusted for confounding factors including age, gender and smoking. bBased on Chisquare test without Yates' correction. Bold value indicates statistical significance. 
rs243845, alone or together with TT, could serve as a protective biomarker for asthma in Taiwan. Although the finding is not consistent with that of the only one group having investigated the contribution of $M M P 2$ genotype to asthma (13), and the detail mechanisms are still unrevealed, the findings are interesting and should be explored further. Two possible explanations behind the differences between the current study with the previous one are: i) the genetic background of the investigated populations (Taiwanese vs Caucasian), and ii) differences in the sample size (our cohort involved 198 asthma patients and 453 non-asthmatic subjects while theirs involved 150 patients in each group). In the future, more investigations including different ethnic backgrounds and larger cohorts would be useful to validate the significance of the $M M P 2$ rs243845 genotypes in asthma risk.

MMP2 protein is critically important in the regulation of extracellular components by metabolizing its various subtracts (30). In the literature, overexpressed MMP2 has been reported in several tumor sites, and is correlated with poor prognosis in melanoma, colorectal, breast, ovarian, prostate and lung cancer (35). Now, we found that the $M M P 2$ rs243845 is associated with a decreased risk of asthma. The genotype at $M M P 2$ rs243845 has been reported to enhance the occurrence rates of bladder cancer (36) and sclerosing cholangitis (37).

Concerning molecular interactions, the promoter region of $M M P 2$ bears specific binding cites for several transcription factors, including activator protein-1 (AP-1), specificity protein-1 (SP-1) and activator protein-2 (AP-2), which can regulate the transcriptional activity of $\operatorname{MMP} 2(38,39)$. The most direct evidence strengthening the importance of $M M P 2$ rs243845 genotypes comes from two studies. The first one found that substituting the $\mathrm{C}$ nucleotide with a $\mathrm{T}$ in $M M P 2$ rs243845 inactivated the SP-1 binding region and led to down-regulation of the transcriptional and translational expression levels of MMP2 (40). The second study revealed that MMP2 is indeed overexpressed among people carrying the CC genotype in MMP2 rs243845, compared to those with the CT and TT genotypes (41). In addition, the MMP2 activity was enhanced in people carrying the $M M P 2$ rs243845 CC genotype, compared to those carrying the variant CT and TT genotypes (41). The genotypephenotype correlation in the MMP2 rs243845 SNPs and their contribution to asthma etiology should be revealed through further investigations

We are interested in further investigating the genotypes of other MMPs, such as MMP9, which will also help understanding its role in ECM dysregulation and how this is involved in asthma etiology. In addition to $M M P 9$, several other genes whose coded protein products closely interact with MMP2, such as the chemokine (C-C motif) ligand (CCL7) (42), tissue inhibitor of metalloproteinases 2 (TIMP 2) $(43,44)$, tissue inhibitor of metalloproteinases 4 (TIMP 4)
$(45,46)$, thrombospondins 1 and 2 (THBS 1, THBS 2) (47), are also in our interest to examine in the future.

In conclusion, these results provide evidence that the variant CT genotypes at the $M M P 2$ promoter rs 243845 may play a role in determining susceptibility to asthma in the Taiwanese.

\section{Conflicts of Interest}

The Authors declare no conflicts of interest with regard to this study.

\section{Authors' Contributions}

Research design was done by CLH, CKL and HTC; patient and questionnaire summaries by HTC and STC; experimental work by CWS and TCW; statistical analysis by LCH, SYC, and LYH; manuscript writing by CLH and BDT; manuscript review and revision by TCW and BDT.

\section{Acknowledgements}

The Authors thank Tissue Bank of China Medical University Hospital for their excellent technical assistance in collection the information, data and samples. The excellent genotyping work performed by Kai-Cheng Chan, Yu-Ting Chin, Tai-Lin Huang, YiRu Huang and Yu-Hsin Lin in Terry Fox Cancer Research Lab was also appreciated by all the Authors. This study was supported mainly by Taichung Tzu Chi Hospital (TTCRD109-06) to Dr. Chiu.

\section{References}

1 Holgate ST: Genetic and environmental interaction in allergy and asthma. J Allergy Clin Immunol 104(6): 1139-1146, 1999. PMID: 10588993. DOI: 10.1016/s0091-6749(99)70005-9

2 Madore AM, Perron S, Turmel V, Laviolette M, Bissonnette EY and Laprise C: Alveolar macrophages in allergic asthma: an expression signature characterized by heat shock protein pathways. Hum Immunol 71(2): 144-150, 2010. PMID: 19913588. DOI: 10.1016/j.humimm.2009.11.005

3 Steinke JW, Rich SS and Borish L: 5. Genetics of allergic disease. J Allergy Clin Immunol 121(2 Suppl): S384-387; quiz S416, 2008. PMID: 18241687. DOI: 10.1016/j.jaci.2007.07.029

4 Himes BE, Hunninghake GM, Baurley JW, Rafaels NM, Sleiman P, Strachan DP, Wilk JB, Willis-Owen SA, Klanderman B, LaskySu J, Lazarus R, Murphy AJ, Soto-Quiros ME, Avila L, Beaty T, Mathias RA, Ruczinski I, Barnes KC, Celedon JC, Cookson WO, Gauderman WJ, Gilliland FD, Hakonarson H, Lange C, Moffatt MF, O'Connor GT, Raby BA, Silverman EK and Weiss ST: Genome-wide association analysis identifies PDE4D as an asthma-susceptibility gene. Am J Hum Genet 84(5): 581-593, 2009. PMID: 19426955. DOI: 10.1016/j.ajhg.2009.04.006

5 Mattiuzzi C and Lippi G: Worldwide asthma epidemiology: insights from the Global Health Data Exchange database. Int Forum Allergy Rhinol 10(1): 75-80, 2020. PMID: 31645084. DOI: 10.1002/alr.22464

6 Koppelman GH: Gene by environment interaction in asthma. Curr Allergy Asthma Rep 6(2): 103-111, 2006. PMID: 16566859. DOI: $10.1007 / \mathrm{s} 11882-006-0047-y$ 
7 Barton SJ, Koppelman GH, Vonk JM, Browning CA, Nolte IM, Stewart CE, Bainbridge S, Mutch S, Rose-Zerilli MJ, Postma DS, Maniatis N, Henry AP, Hall IP, Holgate ST, Tighe P, Holloway JW and Sayers I: PLAUR polymorphisms are associated with asthma, PLAUR levels, and lung function decline. J Allergy Clin Immunol 123(6): 1391-1400 e1317, 2009. PMID: 19443020. DOI: 10.1016/j.jaci.2009.03.014

8 Ober C and Hoffjan S: Asthma genetics 2006: the long and winding road to gene discovery. Genes Immun 7(2): 95-100, 2006. PMID: 16395390. DOI: 10.1038/sj.gene.6364284

9 Zhang J, Pare PD and Sandford AJ: Recent advances in asthma genetics. Respir Res 9(1): 4, 2008. PMID: 18197984. DOI: 10.1186/1465-9921-9-4

10 Woessner JF, Jr.: Matrix metalloproteinases and their inhibitors in connective tissue remodeling. FASEB J 5(8): 2145-2154, 1991. PMID: 1850705.

11 Pascual RM and Peters SP: Airway remodeling contributes to the progressive loss of lung function in asthma: an overview. J Allergy Clin Immunol 116(3): 477-486, 2005. PMID: 16159612. DOI: $10.1016 /$ j.jaci.2005.07.011

12 Murphy G and Docherty AJ: The matrix metalloproteinases and their inhibitors. Am J Respir Cell Mol Biol 7(2): 120-125, 1992. PMID: 1497900. DOI: 10.1165/ajrcmb/7.2.120

13 Toujani S, Mehiri N, Hamzaoui K, Hadded H, Ben Salah N, Mjid M, Ouahchi Y, Louzir B, Daghfous J, Cherif J and Beji M: Role of metalloproteinases MMP-2 in asthma. Tunis Med 94(6): 167-171, 2016. PMID: 19684603. DOI: 10.1038/ng.432

14 Holla LI, Vasku A, Stejskalova A and Znojil V: Functional polymorphism in the gelatinase B gene and asthma. Allergy 55: 900-901, 2000. PMID: 28051223.

15 Ganter K, Deichmann KA and Heinzmann A: Association study of polymorphisms within matrix metalloproteinase 9 with bronchial asthma. Int J Immunogenet 32(4): 233-236, 2005. PMID: 16026590. DOI: 10.1111/j.1744-313X.2005.00516.x

16 Lose F, Thompson PJ, Duffy D, Stewart GA and Kedda MA: A novel tissue inhibitor of metalloproteinase-1 (TIMP-1) polymorphism associated with asthma in Australian women. Thorax 60(8): 623-628, 2005. PMID: 16061701. DOI: 10.1136/thx.2004. 026930

17 Nakashima K, Hirota T, Obara K, Shimizu M, Doi S, Fujita K, Shirakawa T, Enomoto T, Yoshihara S, Ebisawa M, Matsumoto K, Saito H, Suzuki Y, Nakamura Y and Tamari M: A functional polymorphism in MMP-9 is associated with childhood atopic asthma. Biochem Biophys Res Commun 344(1): 300-307, 2006. PMID: 16631427. DOI: 10.1016/j.bbrc.2006.03.102

18 Erbek SS, Yurtcu E, Erbek S and Sahin FI: Matrix metalloproteinase-9 promoter gene polymorphism $(-1562 \mathrm{C}>\mathrm{T})$ in nasal polyposis. Am J Rhinol Allergy 23(6): 568-570, 2009. PMID: 19958602. DOI: 10.2500/ajra.2009.23.3371

19 Pinto LA, Depner M, Klopp N, Illig T, Vogelberg C, von Mutius E and Kabesch M: MMP-9 gene variants increase the risk for non-atopic asthma in children. Respir Res 11(1): 23, 2010. PMID: 20181264. DOI: 10.1186/1465-9921-11-23

20 Hong Z, Lin YM, Qin X and Peng JL: Serum MMP-9 is elevated in children with asthma. Mol Med Rep 5(2): 462-464, 2012. PMID: 22052126. DOI: 10.3892/mmr.2011.656

21 Jimenez-Morales S, Martinez-Aguilar N, Gamboa-Becerra R, Jimenez-Ruiz JL, Lopez-Ley D, Lou H, Saldana-Alvarez Y, Dean $\mathrm{M}$ and Orozco L: Polymorphisms in metalloproteinase-9 are associated with the risk for asthma in Mexican pediatric patients. Hum Immunol 74(8): 998-1002, 2013. PMID: 23639553. DOI: $10.1016 /$ j.humimm.2013.04.036

22 Ye S: Polymorphism in matrix metalloproteinase gene promoters: implication in regulation of gene expression and susceptibility of various diseases. Matrix Biol 19(7): 623-629, 2000. PMID: 11102751. DOI: 10.1016/s0945-053x(00)00102-5

23 Tsai CW, Hsu HM, Wang YC, Chang WS, Shih LC, Sun KT, Hung YW, Yang YC, Gong CL and Bau DT: Contribution of MMP2 promoter genotypes to oral cancer susceptibility, recurrence and metastasis in Taiwan. Anticancer Res 38(12): 6821-6826, 2018. PMID: 30504396. DOI: 10.21873/anticanres.13055

24 Hsu SW, Gong CL, Hsu HM, Chao CC, Wang YC, Chang WS, Tsai YT, Shih LC, Tsai CW and Bau DT: Contribution of matrix metalloproteinase-2 promoter genotypes to nasopharyngeal cancer susceptibility and metastasis in Taiwan. Cancer Genomics Proteomics 16(4): 287-292, 2019. PMID: 31243109. DOI: $10.21873 / \operatorname{cgp} .20133$

25 Waleh NS, Murphy BJ and Zaveri NT: Increase in tissue inhibitor of metalloproteinase-2 (TIMP-2) levels and inhibition of MMP-2 activity in a metastatic breast cancer cell line by an anti-invasive small molecule SR13179. Cancer Lett 289(1): 111118, 2010. PMID: 19751965. DOI: 10.1016/j.canlet.2009.08.006

26 Chen GL, Wang SC, Shen TC, Tsai CW, Chang WS, Li HT, Wu $\mathrm{CN}$, Chao CY, Hsia TC and Bau DT: The association of matrix metalloproteinas-2 promoter polymorphisms with lung cancer susceptibility in Taiwan. Chin J Physiol 62(5): 210-216, 2019. PMID: 31670285. DOI: 10.4103/CJP.CJP_43_19

27 Groblewska M, Mroczko B, Kozlowski M, Niklinski J, Laudanski $\mathrm{J}$ and Szmitkowski M: Serum matrix metalloproteinase 2 and tissue inhibitor of matrix metalloproteinases 2 in esophageal cancer patients. Folia Histochem Cytobiol 50: 590-598, 2012. PMID: 23264224. DOI: 10.5603/20327

28 Kapral M, Wawszczyk J, Jurzak M, Dymitruk D and Weglarz L: Evaluation of the expression of metalloproteinases 2 and 9 and their tissue inhibitors in colon cancer cells treated with phytic acid. Acta Pol Pharm 67(6): 625-629, 2010. PMID: 21229878.

29 Patel BP, Shah PM, Rawal UM, Desai AA, Shah SV, Rawal RM and Patel PS: Activation of MMP-2 and MMP-9 in patients with oral squamous cell carcinoma. J Surg Oncol 90(2): 81-88, 2005. PMID: 15844188. DOI: $10.1002 /$ jso.20240

30 Nagase $\mathrm{H}$ and Woessner JF Jr.: Matrix metalloproteinases. J Biol Chem 274(31): 21491-21494, 1999. PMID: 10419448. DOI: $10.1074 / \mathrm{jbc} .274 .31 .21491$

31 Hsiao, WY, Tsai CW, Chang WS, Wang S, Chao CY, Chen WC, Shen TC, Hsia TC and Bau DT: Association of polymorphisms in DNA repair gene XRCC3 with asthma in Taiwan. In Vivo 32(5): 1039-1043, 2018. PMID: 30150425. DOI: 10.21873/invivo.11344

32 Chen LH, ShenTC, Li CH, Chiu KL, Hsiau YC, Wang YC, Gong CL, Wang ZH, Chang WS, Tsai CW, Hsia TC and Bau DT: The significant interaction of excision repair crosscomplementing group 1 genotypes and smoking to lung cancer risk. Cancer Genomics Proteomics 17(5): 571-577, 2020. PMID: 32859635. DOI: $10.21873 / \mathrm{cgp} .20213$

33 Shih LC, Chang WS, Lee HT, Wang YC, Wang ZH, Chao CY, Yu CC, Lin HY, Shen TC, Kuo CC, Tsai CW and Bau DT: Interaction of interleukin-16 genotypes with betel quid chewing behavior on oral cancer in Taiwan. In Vivo 34(4): 1759-1764, 2020. PMID: 32606144. DOI: 10.21873/invivo.11969

34 Wu MF, Wang YC, Shen TC, Chang WS, Li HT, Liao CH, Gong CL, Wang ZH, Tsai CW, Hsia TC and Bau DT: Significant 
association of interleukin-16 genetic variations to taiwanese lung cancer. In Vivo 34(3): 1117-1123, 2020. PMID: 32354900. DOI: 10.21873/invivo. 11883

35 Bjorklund $\mathrm{M}$ and Koivunen E: Gelatinase-mediated migration and invasion of cancer cells. Biochim Biophys Acta 1755(1): 3769, 2005. PMID: 15907591. DOI: 10.1016/j.bbcan.2005.03.001

36 Wieczorek E, Reszka E, Jablonowski Z, Jablonska E, Krol MB, Grzegorczyk A, Gromadzinska J, Sosnowski M and Wasowicz W: Genetic polymorphisms in matrix metalloproteinases (MMPs) and tissue inhibitors of MPs (TIMPs), and bladder cancer susceptibility. BJU Int 112(8): 1207-1214, 2013. PMID: 23819551. DOI: $10.1111 /$ bju. 12230

37 Korkmaz KS, de Rooij BJ, van Hoek B, Janse M, Coenraad MJ, van der Reijden JJ, Weersma RK, Porte RJ, Voorneveld PW, Baranski AG and Verspaget HW: MMP-2 is a disease-modifying gene in primary sclerosing cholangitis. Liver Int 34(2): 274-280, 2014. PMID: 23809662. DOI: 10.1111/liv.12237

38 Singh N, Hussain S, Sharma U, Suri V, Nijhawan R, Bharadwaj $\mathrm{M}$ and Sobti RC: The protective role of the $-1306 \mathrm{C}>\mathrm{T}$ functional polymorphism in matrix metalloproteinase- 2 gene is associated with cervical cancer: implication of human papillomavirus infection. Tumour Biol 37(4): 5295-5303, 2016. PMID: 26561467. DOI: 10.1007/s13277-015-4378-y

39 Eftekhary H, Ziaee AA, Yazdanbod M, Shahpanah M, Setayeshgar A and Nassiri M: The influence of matrix metalloproteinase-2, -9 , and -12 promoter polymorphisms on Iranian patients with oesophageal squamous cell carcinoma. Contemp Oncol (Pozn) 19(4): 300-305, 2015. PMID: 26557778. DOI: $10.5114 /$ wo.2015.48569

40 Price SJ, Greaves DR and Watkins H: Identification of novel, functional genetic variants in the human matrix metalloproteinase- 2 gene: role of $\mathrm{Sp} 1$ in allele-specific transcriptional regulation. J Biol Chem 276(10): 7549-7558, 2001. PMID: 11114309. DOI: $10.1074 /$ jbc.M010242200

41 Bchir S, Nasr HB, Anes AB, Benzarti M, Garrouch A, Tabka Z and Chahed K: MMP-2 (-1306 C/T) polymorphism affects serum matrix metalloproteinase (MMP)-2 levels and correlates with chronic obstructive pulmonary disease severity: A casecontrol study of MMP-1 and -2 in a Tunisian population. Mol Diagn Ther 20(6): 579-590, 2016. PMID: 27412345. DOI: 10.1007/s40291-016-0225-0
42 McQuibban GA, Gong JH, Tam EM, McCulloch CA, ClarkLewis I and Overall CM: Inflammation dampened by gelatinase A cleavage of monocyte chemoattractant protein-3. Science 289(5482): 1202-1206, 2000. PMID: 10947989. DOI: 10.1126/ science.289.5482.1202

43 Morgunova E, Tuuttila A, Bergmann U and Tryggvason K: Structural insight into the complex formation of latent matrix metalloproteinase 2 with tissue inhibitor of metalloproteinase 2 . Proc Natl Acad Sci USA 99(11): 7414-7419, 2002. PMID: 12032297. DOI: $10.1073 /$ pnas.102185399

44 Overall CM, Tam E, McQuibban GA, Morrison C, Wallon UM, Bigg HF, King AE and Roberts CR: Domain interactions in the gelatinase A.TIMP-2.MT1-MMP activation complex. The ectodomain of the 44-kDa form of membrane type-1 matrix metalloproteinase does not modulate gelatinase A activation. J Biol Chem 275(50): 39497-39506, 2000. PMID: 10991943. DOI: $10.1074 /$ jbc.M005932200

45 Bigg HF, Shi YE, Liu YE, Steffensen B and Overall CM: Specific, high affinity binding of tissue inhibitor of metalloproteinases-4 (TIMP-4) to the COOH-terminal hemopexin-like domain of human gelatinase A. TIMP-4 binds progelatinase A and the COOH-terminal domain in a similar manner to TIMP-2. J Biol Chem 272(24): 15496-15500, 1997. PMID: 9182583. DOI: $10.1074 / j b c .272 .24 .15496$

46 Kai HS, Butler GS, Morrison CJ, King AE, Pelman GR and Overall CM: Utilization of a novel recombinant myoglobin fusion protein expression system to characterize the tissue inhibitor of metalloproteinase (TIMP)-4 and TIMP-2 C-terminal domain and tails by mutagenesis. The importance of acidic residues in binding the MMP-2 hemopexin C-domain. J Biol Chem 277(50): 48696-48707, 2002. PMID: 12374789. DOI: 10.1074/jbc.M209177200

47 Bein K and Simons M: Thrombospondin type 1 repeats interact with matrix metalloproteinase 2. Regulation of metalloproteinase activity. J Biol Chem 275(41): 32167-32173, 2000. PMID: 10900205. DOI: 10.1074/jbc.M003834200

Received September 14, 2020

Revised October 4, 2020

Accepted October 5, 2020 